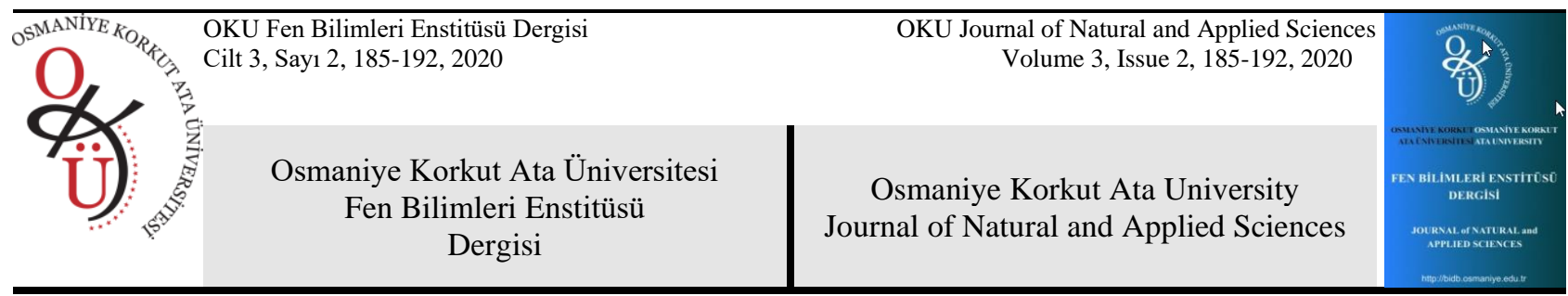

\title{
Hayvansal Ürünlerde Yem Kaynaklı Toksik Maddeler
}

\section{Dilek ŞENTÜRK DEMIIREL ${ }^{1 *}$, Ramazan DEMİREL ${ }^{2}$}

${ }^{1}$ Dicle Üniversitesi, Ziraat Fakültesi, Zootekni Bölümü, 21280, Diyarbakır

${ }^{2}$ Dicle Üniversitesi, Ziraat Fakültesi, Zootekni Bölümü, 21280, Diyarbakır

${ }^{1}$ https://orcid.org/0000-0003-4142-2632

${ }^{2}$ https://orcid.org/0000-0003-0816-4125

*Sorumlu yazar: senturk@dicle.edu.tr

\section{Derleme ÖZET}

Makale Tarihçesi:

Geliş tarihi: 16 Temmuz 2020

Kabul tarihi:28 Eylül 2020

Online Yayınlanma: 15 Aralık 2020

\section{Anahtar Kelimeler:}

GDO

Hayvan besleme

Toksik maddeler

Yem
Günümüzde tarım alanları, artan ve genişleyen yollar, fabrikalar ve insan yerleşimi nedeniyle giderek azalırken, ayrıca erozyon ve bilinçsiz tarım uygulamaları nedeniyle de arazilerin verimliliği de azalmaktadır. Bu durumda hızla artan nüfusun, sağlıklı ve dengeli olarak beslenmesindeki güçlükler de artmaktadır. Özellikle sezon dışı ürünlerde aroma, renk, kıvam vb. özellikler de olumsuz şekilde değişmiştir. Zamanla tüketiciler bilinçlendikçe ve gelirleri arttıkça, doğal olarak yetiştirilen ürünlerin talebi artmaktadır. Ancak artan bu ilginin başlıca nedenlerinden birisi de karma yem tüketen hayvanların ürünleri hakkındaki olumsuz yargılardır. Toplumun bir kesimi karma yem tüketen hayvanların ürünlerinin insanlarda sağlık problemleri oluşturacağını iddia etmektedirler. Basın yayın organları da konu uzmanı olmayan kişilerin görüşlerine yer vererek bu olumsuz algıyı körüklemektedir. Toplumu yönlendirebilme potansiyeli olan kişilerin bilimsel gelişmeler 1şı̆̆ında mevcut teknolojik bilgi ve tecrübeleri herhangi bir çıkar grubuna destek olmaksızın nesnel olarak aydınlatma zorunluluğu bulunmaktadır.

\section{Feed Born Toxic Substances in Animal Products}

\section{Review}

Article History:

Received:16 July 2020

Accepted:28 September 2020

Published online: 15 December 2020

\section{Keywords:}

GMO

Animal nutrition

Toxic substances

Feed

\begin{abstract}
At present, farmlands are getting decrease because of increasing and widening roads, big scale factories and human settlements. Additionally, soil erosion and unconscious agricultural applications lead to profitability problems. Under the circumstance, it's difficult to meet the food requirements of an increasing population as healthy and well balanced. Especially grown as off-season products don't have a real aroma, color, flavor, degree of density, etc. In time, higher incomed and conscious consumers lead to increasing demands for naturally produced foods. However, the reason for increasing demand is suspicion at some animal originated foods, especially fed concentrated feeds. Some people believe there will be health problems if they consume an animal product fed by concentrated feeds. Some media organs lead to a negative impression on the subject by giving place to unauthorized people instead of specialists. Considering scientific improvements, specialists independently illuminate the society on animal protein sources fed by concentrated feed.
\end{abstract}

To Cite: Demirel DŞ., Demirel R. Hayvansal Ürünlerde Yem Kaynaklı Toksik Maddeler. Osmaniye Korkut Ata Üniversitesi Fen Bilimleri Enstitüsü Dergisi 2020; 3(2): 185-192.

\section{Giriş}

Bilim insanları hızla artan nüfusun beslenme sorununu çözebilmek için çeşitli arayışlar içine girmişlerdir. $\mathrm{Bu}$ amaçla doğal melezleme 
yöntemleriyle hızla gelişen, yüksek verimli bitki çeşitleri ile kültür ırkı çiftlik hayvanlarını elde etmişlerdir. Genetik yapısı değişen bitkilerin verimliliğini sağlamak için toprakta eksik bulunan mineraller kompoze gübrelerle verilmiş, verimi artan bitki ve hayvanların adaptasyon problemleri nedeniyle sağlık problemleri ortaya çıktığında ise kaçınılmaz olarak tarım ve veteriner ilaçlarının kullanımı artmıştır. Ancak zamanla üretim artışına rağmen insanların açlik sorunu tam olarak çözülemediği gibi, kullanılan ilaç ve gübrelerden kaynaklanan sağlık sorunları ciddi boyutlara ulaşmıştır. $\mathrm{Bu}$ arada özellikle sezon dişı bitkisel ürünlerde verim artışına odaklanırken tat, aroma, renk, kıvam vb. özellikler de kaybolmuştur. Sezon dışında üretilen meyvelerin doğal renk ve kokusu yetersiz olduğu için, bunlar pazarlarda kimyasallarla sağlanmaktadır. İnsanların gelir seviyesi yükseldikçe doğal ürünlere olan talep artmıştır.

Günümüzde çeşitli basın yayın organlarında çıkan haberler ve konuşmacilardan etkilenen toplumun kafası karışmaktadır. TV ekranlarına çıkan bazı konuşmacılar karma yem tüketen hayvanların ürününün tüketilmemesini söyleyecek kadar konuyu abartmışlardır. Karma yemden, adeta petrol türevlerinden elde edilen suni bir materyalmiş gibi bahsetmektedirler. Oysa karma yemler adeta bebek maması titizliğinde hazırlanan, insanların da günlük hayatta tükettikleri tahılların ağırlıkta olduğu, protein kaynağı olan yağlı tohum küspeleriyle, vitamin mineral karmalarıyla desteklenmiş oldukça dengeli ve besleyici yemlerdir. Gelişmiş ülkelerdeki hayvansal üretim yüksek verimli kültür 1rkı hayvanlarla, dengeli ve besleyici karma yemler kullanılarak yapılmaktadır. Yine gelişmiş ülkelerde kişi başına tüketilen hayvansal ürün miktarı bizim birkaç katımızdır. Ayrıca, günümüzde neredeyse herkes tarafindan yüceltilen ekstansif hayvansal üretimde, doğada beslenen hayvanlar bozulmuş ve çürümüş olan bitkisel ve hayvansal kaynakları da tüketmektedirler. Üretilen karma yemlerde kullanilan hammaddeden itibaren yem üretim sürecinde gerekli hijyen koşullarına uyulması ve kamu otoritesi tarafindan gerekli denetimlerin usulüne göre yapılması gerekir. Bu makaleyle, bitki ve hayvanların genetik yapılarına ilave olarak hayvan yemlerinden (yemin yapisındaki antibesinsel maddeler, hasat, işleme, nakliye, depolama vb.) kaynaklanabilecek sağlık riski oluşturabilme potansiyeli olan toksik maddeler ve bunlardan kaçınma yolları konusunda insanların doğru bir şekilde bilgilendirilmelerine katkıda bulunulması amaçlanmıştır.

\section{Yem Kaynaklı Potansiyel Toksik Maddeler}

Ağız, solunum veya deri yoluyla alındığında belirli dozda veya zaman içerisinde yaşayan hücre ve dokulara kimyasal, biyokimyasal ya da radyoaktif nitelikte zarar veren, etkisini en küçük dozlarda bile gösteren maddelere toksin denir [1,2]. Hayvansal gidaların güvenliği tüketilen yemlerin biyolojik, kimyasal veya fiziksel olarak içerdikleri tehlikelerden etkilenebilir. Olası tehlikelerin kaynakları ile bulaşma yolları farklı olabilir. Tehlike; yem ham maddelerinden, yem işleme, depolama, nakliye ve hatta hayvanların yemi tükettikleri süredeki etkileşimlerden ve bulaşmalardan kaynaklanabilir.

\subsection{Genetiği değiştirilmiş organizmalar (GDO)}

Bir canlıdaki genetik özelliklerin (yüksek verim, erkencilik vb. özelliklerinin yanı sıra; kışa, kuraklığa, tuzluluğa, hastalık ve zararlılara dayanıklılık) taşınarak, bu vasıfları içermeyen bir diğer canlıya aktarılmasıyla geliştirilen yeni bireye "genetiği değiştirilmiş organizma (GDO)" denir. GDO teknolojisi günümüzde, çeşitli zararlılara (mısır, pamuk), böcek ilaçlarına (kanola, soya), çeşitli virüs hastalıklarına (papaya, kabak) dayanıklı çeşitlerin geliştirilmesinde kullanılmaktadır.

Günümüzde çabuk etkilenen tüketicilerin en hassas oldukları konulardan birisi de GDO içeren ürünlerdir. Akademik çevreler de bu konuda ikiye bölünmüştür. Bazıları GDO'nun artan nüfusun beslenmesinde ve bazı tarım ilaçlarının azaltılmasında anahtar rol oynayacağı görüşünde olup, GDO'lu ürünlerin hayvan ve insan sağlığ üzerine olumsuz etkili olduğunu gösteren bilimsel yayının olmadığını ifade etmektedirler. Karşı taraftaki bilim insanları ise bilimsel araştırmaları destekleyen kurum ve kuruluşların genellikle küresel tohum ve ilaç şirketleri olması nedeniyle çalışmalardan elde edilen sonuçların yayın haklarını ellerinde bulundurduklarını ve dolayısı ile olumsuz sonuçları gizlediklerini, yayımlanmasına izin vermediklerini ifade etmektedirler. Ayrıca GDO teknolojisinin çok yeni olmasi nedeniyle uzun yıllar sonunda neleri değiştireceğinin bilinmemesi bir diğer handikaptır. GDO'lu tohumların yaygın kullanımı sonucu gen kaçışıyla doğal bitki çeşitliliğini azaltması veya küresel şirketlerin tekeline alınarak küçük üreticinin bu tekellere mahkûm edilmesi 
diğer sakıncalardır. GDO’lu ürünün patentine sahip şirketlerin desteklediği akademik çalışmalarda kullanılan hayvan türü, yaşı, deneme süresi hakkında da eleştiriler bulunmaktadır. Denemelerde kullanılan hayvan sayısının kasitlı olarak az tutulduğu, genç hayvanların kısa süreli (3 ay) beslenerek hastalık belirtilerinin ortaya çıkmasından (4-7 ayda ortaya çıktığ 1 belirtiliyor) önce denemelerin sonlandırıldığı ifade edilmektedir. Doğada binlerce yılda meydana gelen mutasyonla da canlıların genetik yapıları değişmektedir. Günümüzde yetiştirilen birçok farklı bitki çeşidi ve hayvan ırkı doğal mutasyonlarla meydana gelmişlerdir. GDO'lu yemlerle yapilan hayvan besleme denemelerinin olumsuz özellik taşıyanlarının çeşitli uluslararası saygın yayın organlarında basılmadığı veya bir süre sonra sağlanan maddi imkanlarla ironik olarak makaleyi basan dergi yayın kuruluna müdahale edilerek değiştirildiği ifade edilmektedir [3].

Halen ülkemizde gıda amaçlı GDO'lu ürünlerin kullanımı yasak olup, 14 GDO'lu mısır ve 3 soya çeşidinin yem amaçlı kullanımına izin verilmektedir [4]. Bazı bilim insanları GDO'lu ürünlerin doğrudan insan gidası olarak kullanılması yerine, hayvan yemi olarak kullanılmasiyla önce hayvanın sindirim sisteminde en küçük bileşenlerine ayrılacağını daha sonra bu hayvanın ürünlerinin tüketilmesinin herhangi bir sakınca yaratmayacağını ifade etmektedirler. Yine GDO'lu ürünlerin DNA fraksiyonlarının hayvan ve insan vücudunda bulunduğuna dair çalışmalar da mevcuttur. Ancak, hayvansal protein fraksiyonu olan prionun deli dana hastalığına neden olduğunun da unutulmaması gerekir.

Hayvancılık alanında transgenik ürünlerin kullanımı; yemden yararlanma kabiliyetlerinin artırılması için protein miktarı ve kalitesinin yanı sıra, nişasta ve yă bileşiminin, vitamin ve mineral kapsamlarının iyileştirilmesi ile besin değeri taşımayan yem bileşenlerinin (proteaz inhibitörleri, lektin vb.) azaltılarak hayvanların yemi daha iyi ürüne dönüştürerek, hayvancıllı̆ karlı hale getirmiştir [5]. Bu konuyla ilgili bilim insanları farklı alanlarda çalışmalar yapmakta, elde edilen başarılı sonuçlar pratiğe geçirilmekte ve dolayısı ile konu hakkında çeşitli tartışmalar da kaçınılmaz olarak artarak devam etmektedir.

Bazı araştırıcılar, transgenik ürünlerin gelecekte yıllarda insan ve hayvan sağlığı üzerine olumsuz etki potansiyelinin (alerjik veya toksik) olabileceğini ifade ederken, bazıları önüne geçilemeyecek boyutta çevresel problemlerin meydana gelebileceğini, diğer bazıları da üretimin izole yerlerde kontrol altında yapilmasiyla, s1k1 denetim ve testlerinin yapilarak sorunların çözülebileceğini ifade etmektedirler [6].

Geleneksel olarak yetiştirilenler ile genetik yapıları değiştirilen bitkilerden üretilen yemlerin besin madde içerikleri karşılaştırıldığında; yemlerin sindirilebilirliği ve verim bakımından önemli düzeyde farklı1ığın bulunmadığı anlaşılmaktadır. Ayrıca hayvan organ ve dokularında DNA veya DNA parçacıkları gibi kalıntıların bulunmadığ 1 ifade edilmektedir [7]. Bunun yanında modern biyoteknoloji ile elde edilen ürünler alerji ve toksisite yönünden incelemeye ilave olarak, besin maddesi içerikleri, yem potansiyeli, ekonomikliği gibi kriterler açısından da her yeni gen ve ortam için incelenmeye alınarak insan ve hayvan sağlığ açısından mutlaka değerlendirmeye tabi tutulmalıdır. $\mathrm{Bu}$ nedenle transgenik bitkilerin güvenliği nedeniyle hala insanların kafasında soru işaretleri vardır ve biyogüvenlik kaygısı her zaman gündemdeki yerini koruyacaktır.

\subsection{Hayvansal protein kaynaklarl ve deli dana hastalığ (BSE)}

Bovine spongiform ensefaliti (BSE), 1996 yılında İngiltere başta olmak üzere bazı AB ülkelerinde ciddi ekonomik kayıplara neden olmuştur. $\mathrm{AB}$ ülkeleri İngiltere'den et ithalatını kısıtlamış ve yaklaşık 1.5 milyon sığır itlaf edilmiştir. Birlik ile İngiltere arasında ticaret savaşı çıkmıştır. Ülkemizde deli dana hastalığı korkusu nedeniyle $\mathrm{AB}$ ülkelerinden 2010 yılına kadar 14 yıl süresince canlı hayvan ve et ithalatına izin verilmemiştir [8]. Yüksek verimli sığır yemlerine korunmuş protein kaynağ 1 olarak katılan koyun mezbaha ürünlerinden kaynaklanmıştır. Hayvansal proteinlerin sindirim sistemindeki kuvvetli asidik ortamda proteolitik enzimlerle en küçük bileşenleri olan amino asitlerine ayrılıp, zararsiz hale gelmesi beklenirken, deli dana hastalığının ortaya çıkmasıyla bu konudaki yargılar değişmiştir. Ayrıca çeşitli barsak parazitlerinin sindirim enzimlerine ve asiditeye dayanıklı olan inaktif formlarının bağırsaklarda aktif hale geldiğinin de unutulmaması bu konudaki şüphelerin haklılığını konusunda yararlı olacaktır. Dolayısı ile bugün zararsız denilen GDO'lu ürünlerin sindirim sisteminde tamamen parçalanıp, etkisiz hale getirileceği beklentisi şüphelidir. Günümüzde başta $\mathrm{AB}$ ülkeleri olmak üzere birçok gelişmiş ülkede doğasında et tüketmeyen çiftlik hayvanlarının beslenmelerinde 
hayvansal protein kaynaklarının kullanılması yasaktır. Hatta giderek kanatlı kümes hayvanı yemlerinde de yasaklanması eğilimi ağırlık kazanmaktadır.

\subsection{Antibiyotik ve koksidiyostatlar}

Ülkemiz kişi başına yıllık antibiyotik kullanımı en yüksek ülkelerden birisi olması nedeniyle Sağlık Bakanlığı doktorların hastalara antibiyotik yazımını kısıtlamak zorunda kalmıştır. Zira yoğun olarak kullanılan antibiyotik kirlenmesi sonucu ortamdaki mikroorganizmalarda pasif direnç gelişmekte ve gelecekte süper bakteriler nedeniyle cerrahi operasyonların riskli hale geleceği ifade edilmektedir [9]. İnsan ve hayvanlar için kullanılan antibiyotiklerin benzer spektruma sahip olması nedeniyle pasif dirençten korkulmakta ve tedbir olarak antibiyotik kullanımının azaltılması yönünde tedbirler alınmaktadır.

Günümüzde birim alanda yoğun olarak yapılan modern hayvansal üretim nedeniyle salgın hastalıklar önemli ekonomik kayıplara neden olmaktadır. Ortaya çıkması muhtemel hastalıklara karş1 üretimin garanti altına alınabilmesi için çiftlik hayvanlarının aşılanması gerekir. Ancak bazı hastalıklara karşı aşılar bulunmadığ gibi, antibiyotiklerin düşük dozda yemlerde bulunmasının büyüme geliştirici etkileri de bulunmaktadır. Bu nedenle 1997'ye kadar kanatlı kümes hayvanlarının yemlerinde büyüme geliştirici etkisi nedeniyle zinc bacitracin gibi bazı antibiyotikler kullanılırdı. Ancak AB üyelik sürecinde yapılan düzenlemeler gereği eş zamanlı olarak ülkemizde de yemlerde koruyucu veya yemden yararlanmayı artırıcı olarak antibiyotik kullanımı yasaklandı. Sürüde hastalık çıktığında, aynı insanlarda olduğu gibi antibiyotik kaçınılmaz olarak enfeksiyon bitinceye kadar belirli bir süreyle kullanılmaktadır. Kullanılan antibiyotikler et, süt ve yumurtaya geçmektedir Hastalığın tedavisinde antibiyotik kullanıldığı süre boyunca üretilen hayvansal ürünlerin toplanıp imha edilmesi gerekir. Ancak ülkemizde çoğu zaman düşük kar marjiyla üretim yapan işletmelerimizde hastalığa karşı sigorta yaptırma geleneği yerleşmediği, üreticilerin bilinç düzeyinin düşüklüğü ve denetimlerin eksikliği gibi nedenlerden dolayı ne yazık ki, antibiyotik kullanılan hayvanları ürünleri de pazarlanabilmektedir.

FAO raporlarına göre, tedavi amaciyla hayvanların \%80'inin hayatlarının bazı dönemlerinde veya tamamında içme suları veya yemleriyle antibiyotik aldıkları ifade edilmektedir.
Türkiye'deki hayvancılık işletmelerinde antibiyotikler; sağlık koruma, tedavi veya verimi artırma amaciyla kullanılmaktadır [10].

Yem, su veya enjeksiyonla çiftlik hayvanlarına verilen antibiyotiklerin vücuttan atılma süreleri dikkate alınarak, hayvansal kaynaklı ürünlerde rezidü (kalıntı) denetimlerinin yapılarak, uyulmaması halinde ciddi yaptırımlar getirilmesi ve tüketici sağlığının korunması gerekmektedir. Antibiyotik vb. ilaçların vücuttan atılma süreleri; hayvanın türü, ilacın vücuttaki hareketi, uygulama yolu, kesim öncesi bekletme süresi vb. gibi çeşitli faktörlere göre birkaç günle birkaç hafta arasında değiş̧ebilir [11]. Sütlerde bulunan antibiyotik kalıntıları, çeşitli süt ürünlerinin (yoğurt, kefir vb.) imalatında kullanılan mayaların büyüme gelişmesini engelleyip, ciddi ekonomik kayıplara yol açabilir. Hayvansal kökenli besinlerdeki antibiyotik kalıntıları çeşitli patojen mikroorganizmaları (salmonella $v b$.) bask1 altında tutarak, besinlerin bakteriyolojik analizlerinde hatalı sonuçların elde edilmesine ve veteriner halk sağlığı açısından problemlere yol açabilir.

Karma yemlere katılması yasak olan maddeler farklı zamanlarda ihtiyaç duyulan düzenlemelerle çeşitli kanunlarla tamamlanmıştır. $\mathrm{AB}$ uyum yasaları çerçevesinde yapılan düzenlemelerle, ülkemizde hormon ve antibiyotik büyütme faktörlerinin hayvansal yemlerde kullanımı tamamen yasaklanmıştır. Ancak, bazı hayvan türleri için üretilen vitamin- mineral ön karışımları ile karma yemlerde bazı antikoksidiyallerin kullanılmasına izin verilmektedir [12].

\subsection{Küf mantarlarl ve patojen bakteriler}

Yemin besin madde içeriği yanında mikrobiyolojik ve mikotoksikolojik olarak bulaşıklık durumu önemlidir. Yemin kalitesi hayvanların sağlıklı ve dengeli beslenmeleri için olduğu kadar, hayvansal ürünleri tüketen insanlar için de önemlidir. Karma yem imalatında kullanılan yemlerin (tahıllar, yağlı tohumlar, küspelerin) hasadından, depolanmasına ve karma yem üretim sırasındaki değişik aşamalarda (silolar, taşıyıcılar ve soğutucular vb.) gerekli hijyen kuralları uygulanmazsa, mikrobiyal bulaşma söz konusu olabilir.

Mikotoksinler, zehirli mantarlar tarafindan üretilen sekonder metabolitlerdir. Yemlik materyalde bulaşma tarlada başlar, mantar gelişimine uygun sıcaklık ve nemin sağlanmasıyla süreç hızlanır. Ürünler tarlada genellikle 
Claviceps, Neotyphodium, Fusarium ve Alternaria türü mantarlarla; depolama sirasinda ise Aspergillus ve Penicillium türleriyle enfekte edilirler [13]. $\mathrm{Bu}$ patojen mantarlar yemlere bulaştığında oluşan toksinlerin önemli miktarı, barsaklardan emilmeden atılmakla birlikte, bir miktar hayvansal dokularda birikerek, hayvan sağlığını, daha sonra hayvansal ürünlerin tüketimiyle de insan sağlığını tehdit eder. Aflatoksin $M_{1}$ ve $M_{2}$ süte ve dolayısı ile süt ürünlerine de geçerek insan sağlığı için risk oluşturmaktadır. Mikotoksinlerin başlıcaları; aflatoksinler, okratoksinler, fumonisinler, trikotesenler, zearelenon ve ergot alkoloidleri'dir. Karma yemlerde mantar gelişimini önleyici yem katkıları (propiyonik asit vb.) ile başta kil mineralleri olmak üzere çeşitli toksin bağlayıcılar kullanılmakla birlikte, bunlar yem maliyetini artırmaktadır. Ayrıca tüketiciler gıda ve yemlerdeki katkı maddeleri konusunda oldukça hassaslaştıkları için yemlerde mantar gelişimini engelleyecek koşulların sağlanması temel hedef olmalidir.

Günlük hayatta küf mantarları tarafından salgılananlar en çok karşılaşılan toksinlerdir. FAO kayıtlarına göre, dünya genelindeki tarımsal ürünlerin $\% 25$ ' $\mathrm{i}$ mikotoksinlerle kontamine oldukları, karma yemlerdeki bulaşma oranının yüksek (\%40) olduğu ifade edilmektedir [14].

Mantar toksini kaynaklı zehirlenme olan mikotoksikozis akut, kronik ve latent halde olabilmektedir. Akut durumda yüksek dozlarda toksin yemlerle kısa sürede vücuduna alınarak, toksinin türüne göre; karaciğer, böbrek ve dalakta büyüme, kanama, ishal, iştah kaybı, kusma, ödem ve koma görülebilir. Kronik ve latent zehirlenmeler daha yaygındır ve düşük dozlarda toksini içeren yemlerin uzun süreyle tüketilmesi sonucu; yumurta veriminde, yemden yararlanma ve canlı ağırlıkta azalma ile enfeksiyonlara karşı hayvanların duyarlı hale gelmesi gibi ciddi ekonomik kayıplarla karşılaşııı [15].

Hayvan yemleri arasında toksinlerle en fazla bulaşma riski olanlar mısır, tahıllar, pamuk tohumu küspesi, sorgum ve yer fistığıdır. Hijyen koşullarına dikkat edilmeyen yemlerde mantarların dışında patojen bakterilerden kaynaklanan sağlık riskleri de (enterotoksinler) bulunmaktadır. $\mathrm{Bu}$ bakterilerin bazıları toksinlerini yem içerisinde salgılarken (Clostridium botulinum, Staphyloccus aureus ve Bacillus cereus), bazıları da yemler alındıktan sonra hayvan vücudunda (Salmonella, E. Coli ve Clostridium perfringes) salgilarlar [14].

\subsection{Dioksin ve $P C B$}

Dioksin ve PCB'ler, doğada biyolojik yollarla oluşarak, canlıların gida zinciri yoluyla tüketilen gida ve yemlerde bulaşmaya neden olan, son derece toksik nitelikli, kimyasallardır. Dioksin terimi, yapıları birbirine benzemekle birlikte farklı miktarlarda klor içeren iki kimyasal grubun (dioksin ve furanlar) ortak isimdir. "Polikorlu bifeniller' (PCB'ler) kimyasal aynı türdeki kompleks yapılardır, bileşimlerinde çeşitli seviyelerde klor bulunur. Bu kimyasallarda klorun bağlı bulunduğu pozisyon itibaryla 75 farklı dioksin, 135 furan ve 209 PCB meydana gelmektedir [16].

Bileşimlerinde klor bulunan endüstriyel, tıbbi veya evsel atıkların yanmasıyla, ekzoz ile endüstriyel emisyonlarla, yangınlar, metal tasfiyesi ve rafinasyonuyla dioksin ve furanlar meydana gelir. Ayrıca, bu tip maddeler bina izolasyon malzemelerinin yapılarında da bulunur. Dioksinler kil minerallerinde olduğu gibi, ürünün kendi bünyesinde bulunabilir veya narenciye posasındaki kireç gibi işleme sırasında da ürüne geçebilmektedirler. Yemlerin kurutulmas1 sırasında işlenmiş odun, kalitesiz kömür veya sıvı yakıtlardan ürünlere dioksin geçebilir. Bazı endüstriyel işlemlerin gerçekleştirildiği yerlerde (çöp yakma) yetişen bitkilere de dioksinler bulaşabilir. Doğada yetişen çayır-mera ve yem bitkilerinde dioksinler bulunabilir. Hayvansal gıdalardan kaynaklanan dioksinlerin insanlar için en önemli bulaşma yolu olduğu ifade edilmektedir. Dioksinler, yağ dokuda yüksek düzeylerde birikerek, hayvanın yaşamı boyunca elde edilen et, süt ve yumurta gibi gidalarda kalıntı bırakabilir. Kontamine sularda yetişen balıklarda da dioksinlere rastlanmaktadır. Gida zincirinde dioksinden kurtulmanın yolu yemlerin denetlenmesinden geçmektedir. Dioksinlerin gida yan ürünleri, balık unu ve yağı gibi yan ürünlerden yeme ve dolayısı ile hayvansal ürünlere geçebileceği ifade edilmektedir [17]. Dioksin besi hayvanlarının, katı atıkların yakıldığı firınların yakınında otlatılmaları veya PVC ile işlenmiş tahtadan yapılmış alanlarda beslenmeleri sonucu hayvanlara, etlerinin tüketimiyle de insanlara bulaşır [18].

Dioksinlerin aksine, PCB'ler yanmayla meydana gelmezler. Bunlar; 1sı değişim sistemleri, elektrik izolasyon malzemeleri, yangın kimyasalları, boya, polimer ve tutkallardaki stabilizörler ile madeni yağlardaki kimyasallardır. Gelişmiş ülkelerde PCB kullanımı yaklaşık 25 yıl önce yasaklanmış 
olmasına karşın, yapılarının dayanıklı olması nedeniyle çevresel kirlilik günümüzde hala söz konusudur. Selüloz endüstrisinde ağaç hamurunun beyazlatılması için kullanılan klor, atıklar yoluyla su kaynaklarının kirlenmesine yol açmaktadır. Klorlu bileşiklerden kaynaklanan kirlilik gida ve yem zincirinde de bulaşmaya neden olmaktadır [16].

\subsection{Tarım, haşere ve veteriner ilaçları}

Son aylarda Belçika ve Hollanda başta olmak üzere birçok $\mathrm{AB}$ ülkesinde tavukçuluk sektörünü derinden etkileyen fipronilli yumurta problemi güncelliğini korumaktadır. Kanatlı kümes hayvanlarının haşerelere karşı korunması amacıyla haricen kullanılan fipronil içerikli haşere ilacının etken maddesi yumurta içerisinde tespit edilmiştir. Fipronil, kedi ve köpek gibi eti tüketilmeyen evcil hayvanların bit, kene ve mayt gibi haşerelerine karşı haricen kullanılan bir ilaçtır. Ürünlerinden yararlanılan çiftlik hayvanlarına haricen bile uygulanması yasaktır. Fipronil deriden vücuda geçerek, karaciğer, böbrek ve tiroid bezinde hasar oluşturur. Hollanda'da profesyonel tohum firmaları haşerelere karşı sadece tohumları ilaçlamada ve insan bulunmayan yerlerde hamam böceği ilaçlamalarında kullanılmasına izin verilmektedir. Buna benzer bazı tarım veya veteriner ilaçlarının kalıntıları sıkı denetimlere rağmen hayvansal ürünlerde tolerans değerlerinin üzerinde bulunabilmektedir.

Hayvanlarda hastalık çıktığında kullanılan veteriner ilaçlarından özellikle antibiyotik ve koksidiyostatların kullanıldığ 1 yemlerin üretiminden sonra üretim hattının mutlaka temizlenmesi gerekir. Ayrıca buna benzer ilaç ve hormon kullanıldiysa hayvanın doku ve ürünlerinde kalıntı bırakmayacak şekilde doz ve uygulama süresi dikkate alınmalıdır. Uygulama yapılan dönemde üretilen et, süt ve yumurta gibi gidaların toplanarak imha edilmesi gerekmektedir. Hayvan yemlerinde kullanılan ham maddelerin bazıları yoğun tarım ilacına maruz kalmaktadır. Tarım ilaçları içinde bulunan zararlı maddeler bitki, insan ve hayvan sağlığını olumsuz yönde etkilemektedir. Azotlu gübrelerin fazla kullanımıyla, bitkilerin nitrat içerikleri hayvanlar için toksik düzeylere çıkabilir [19].

Günümüzde dünyada kişi başına yıllık tarım ilacı kullanımı $\quad 0,5 \quad \mathrm{~kg} \quad(1,4 \quad \mathrm{~g}$ günlük $)$ olarak hesaplanmaktadır. Gelişmekte olan ülkelerde yıllık 37 bin kanser vakasının tarım ilaçlarından kaynaklandığı tahmin edilmektedir [1]. Tarımsal zararlılarla mücadele için kullanılan pestisitler, ürün miktarını ve kalitesini artırırken, ürünlerde kalıntıya neden olmaktadır. Gıdalardaki tarım ilaçları teknolojik işlemlerde bir miktar azaltılmakla beraber, yine de bir miktar ürün üzerinde ve içerisinde kalmaktadır. Böylece yanlış zaman ve yüksek dozlarda yapılan tarımsal ilaçlamalardan insan sağllğı olumsuz etkilemektedir [20].

\subsection{Mikrobiyal hastalıklar}

Brusella ve salmonella gibi zoonoz hastalıklar hayvanlardan yemlere ve daha sonra et, süt ve yumurta yoluyla insanlarda sağlık problemi oluşturabilirler. $\mathrm{Bu}$ tip hastalıklardan korunmak için gerekli aşılamalar yapılarak işletmelerde biyogüvenlik kurallarına uyulması gerekir.

\subsection{Ağır metaller}

Ağır metaller ile ilgili farklı tanımlamalar bulunmakla birlikte; genellikle metalin yoğunluğu ve sağlık üzerindeki olumsuz etkileri üzerinde durulmaktadır. Yoğunluğu $5 \mathrm{~g} / \mathrm{cm}^{3}$ ten fazla olan, çevre kirliliği nedeniyle insan sağlığı üzerine olumsuz etkili metal ve metaloidlerdir. Ağır metaller başlıcaları; kurşun, kadmiyum, demir, kobalt, bakır, arsenik, kalay, alüminyum, nikel, c1va, çinko, krom ve selenyum olmak üzere 60'tan fazladır [21].

Tabiatta çoğunlukla karbonat, oksit, silikat ve sülfür halinde stabil bileşik olarak veya silikatların yapısında yer alırlar [22]. Ağır metallerin çevreye yayılmalarının sebebinin insanlar olduğu ifade edilmektedir. Çevreye yayılan ağır metaller; çayır - meralara, tarımsal alanlara, hayvansal ürünlere, kirli sularda avlanan balıklara veya yiyecek üretiminde kullanılan ekipmanlardan bulaşabilmektedir. Ayrıca yer altı ve yüzeysel su kaynaklarına, toprak ile havaya bulaşabilmektedirler [23].

Endüstriyel gelişmenin bir sonucu olarak, endüstriyel tesislerden kaynaklanan atık ve artıklarla yem ve yem hammaddeleri önemli ölçüde kirlenebilmektedir. Kadmiyum döküm yeri ve madencilik yapılan yerlerde yetişen bitkilerde yaygın olarak bulunan bir ağır metaldir. Arsenik ve cıva doğada özellikle deniz kökenli yemlerde olmak üzere birçok yerde bulunurlar. Kurşun da her yerde yaygın bulunan bir ağır metaldir. Ağır metaller karaciğer, böbrek, beyin ve kemik başta olmak üzere çeşitli hayvansal doku ve gıdalarda birikerek sağl1k riski meydana getirirler [24]. 
Arsenik hayvan ve insanlarda zehirlenmelere ve ölümlere neden olan bir elementtir. Arsenik doğada yaygın olarak bulunmakla birlikte, çeşitli endüstriyel alanlarda, hekimlikte ve tarımsal mücadeledeki kimyasalların üretiminde kullanılması nedeniyle sıklıkla gündeme gelmektedir [25].

\section{Sonuç}

Doğal üretim sınırlarının zorlanmasına rağmen, geometrik hızla artan insan nüfusunun sağlıklı ve dengeli beslenebilmesi için ihtiyaç duyulan hayvansal protein kaynaklarının kaliteli karma yemler kullanilarak modern üretim sistemleri içerisinde üretilmesi gerekmektedir. Özellikle ekonomik gelir seviyesi düşük olan insanların, nispeten düşük fiyatları dolayısıyla en kolay erişebileceği hayvansal protein kaynaklarının güvenliği konusunda cesaretlendirilmeleri gerekmektedir. $\mathrm{Bu}$ konuda üreticilerin bilinçlendirilmeleri bunun yanında kamu otoritesinin de gerekli denetimleri yapması büyük öneme sahiptir. Modern hayvansal üretimde yemlerin usulüne göre hazırlanıp, işlenmesi, depolanması ve biyogüvenlik kurallarının sağlanmasıyla hayvansal gidanın üretilmesi ve yem tüketen hayvanların ürünlerinin de güvenle kullanılabileceği konusunda tüketiciler bilinçlendirilmelidir.

\section{Kaynakça}

[1] Ayaz A., Yurttagül M. Besinlerdeki toksik öğeler-I.

https://sbu.saglik.gov.tr/Ekutuphane/kitaplar/ t71.pdf. 2008. (Erişim Tarihi: 29.03.2018).

[2] Anonim. https://tr.wikipedia.org/wiki/Toksin 2017. (Erişim Tarihi: 23.03.2018).

[3] Yalçın S. Saklı seçilmişler, Kırmızı Kedi Yayınevi; 2017.

[4] Tukelman EÖ. Genetiği değiştirilmiş ürünlere karşı üreticilerin farkındalıkları, Doktora Tezi, Fen Bilimleri Enstitüsü, Namık Kemal Üniversitesi, Tekirdağ, Türkiye, 2017.

[5] Çayıroğlu H., Ocak N. Hayvan beslemede genetik yapısı değiştirilmiş ürünler, II. Ulusal Hayvan Besleme Kongresi, 18-20 Eylül 2003, sayfa no: 381-384, Konya.

[6] Hartnell GE. Potential of biotech crops as livestock feed, Advanced Dairy Science and Technology 2000; 113: 249-262.

[7] IFT. Genetically modified organisms (GMO's). A backgrounder by the Institute of Food Technologists. Food Technology 2020; 54(1): 42-45.
[8] Yıldırım AE. Deli dana. http://www.tarimdunyasi.net/2011/12/13/deli -dana/ 2011. (Erişim Tarihi: 10.04.2018).

[9] Çiftçi A., Aksoy A. Antibiyotiklere karşı oluşan direnç mekanizmaları, Türkiye Klinikleri 2015; 1(2): 1-10.

[10] Demir C. Hayvansal gidalardaki antibiyotik ve hormon kalıntıları, http://www.gidahijyeni.com/showarticle.aspx ?ItemID=225\&ItemClass=1 2016. (Erişim Tarihi: 15.04.2018).

[11] Yarsan M. Hayvansal gidalarda kalıntı sorunu, http://www.vetfarmatoks.org.tr/EYarsan_Kal inti.pdf. 2012. (Erişim tarihi:19.03.2018).

[12] Tuncer Hİ. Karma yemlerde kullanımı yasaklanan hormon, antibiyotik, antikoksidiyal ve ilaçlar, Lalahan Hayvancılık Araştırma Enstitüsü Dergisi 2007; 47(1): 29-37.

[13] D'Mello JPF. Contaminants and toxins in animal feeds, FAO Anim Production 2004; 160: 107-128.

[14] Basmacioğlu H., Ergül M. Yemlerde bulunan toksinler ve kontrol yolları, Yem Magazin 2003; 31.

[15] Aydın N. Kanatlı hayvanların önemli mikotik enfeksiyonları ve mikotoksikozisler, Tavukçuluk Bülteni 1989; 46.

[16] Şenyuva H., Gilbert J. Dioksin/PCB analiz gerekliliği, Foodlife International. http://www.sincer.com.tr/HTMLEditorFiles/f ile/Dioksin_Insert.pdf 2004. (Erişim Tarihi: 20.03.2018).

[17] Anonim. Yem sektörü için iyi üretim uygulamaları ve yem hijyeni kılavuzu, https://www.tarim.gov.tr/GKGM/Belgeler/G $\%$ C4\%B1da\%20ve\%20Yem\%20Hizmetleri/ yemhizmetleri/hijyen_kilavuzu.pdf 2014 . (Erişim Tarihi: 29.03.2018).

[18] Vural H. Gıda kirliliği açısından dioksin ve furan izomerleri, Ekoloji Dergisi 1995; 15: 45-49.

[19] Zialdi N., Simard RR., Allard G., Parent G. Yeild response of forage grasses to $n$ fertilizer as related to spring soil nitrate sorbed on anionic exchange membranes. Canadian Journal of Soil Science 2000; 80(1): 203-212.

[20] Ayaz A., Yurttagül M. Besinlerdeki toksik öğeler-II.

https://www.beslenme.gov.tr/content/files/ arastirmalar/uyelik/./b_10_besin_toksik_2_4 0.pdf 2012. (Erişim Tarihi: 29.03.2018).

[21] Duffus JH. Heavy metals- A meaningless term IUPAC technical report, International 
Union of Pure and Applied Chemistry 2002; 74(5): 793-807.

[22] Bakar C., Alper B. Metaller ve insan sağlığı: yirminci yüzyıldan bugüne ve geleceğe miras kalan çevre sağlığı sorunu, 1.Tibbi Jeoloji Çalıştayı, 2009, Nevşehir.

[23] Erkmen O. Gida kaynaklı tehlikeler ve güvenli gida üretimi, Çocuk Sağlı̆ğ ve Hastalıkları Dergisi 2010; 53(3): 220-235.

[24] Anonim. Yem sektörü için iyi üretim uygulamaları ve yem hijyeni kılavuzu, https://www.tarim.gov.tr/GKGM/Belgeler/G $\%$ C4\%B1da\%20ve\%20Yem\%20Hizmetleri/ yemhizmetleri/hijyen_kilavuzu.pdf 2014. (Erişim Tarihi: 29.03.2018).

[25] Kaya S., Bilgili A., Doğan A., Liman BC. Mezbahada kesilen sığırların et ve bazı organlarında arsenik kalıntıları, Ankara Üniversitesi Veteriner Fakültesi Dergisi 1990; 37(2): 359-363. 